Izvorni znanstveni rad DOI: $10.17234 /$ Croatica.42.9

UDK: 81'367:81'373

$811.163 .42 ’ 367.622$

Primljen: 1. XII. 2017.

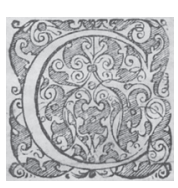

Prihvaćen: 17. I. 2018.

\title{
MOGU LI IMENICE IMATI DOPUNE?
}

\author{
Branimir Belaj \\ Filozofski fakultet Sveučilišta J. J. Strossmayera u Osijeku \\ Odsjek za hrvatski jezik i književnost \\ branimir.belaj@os.t-com.hr
}

Primjenjujući teorijsko-metodološki okvir kognitivne gramatike, u ovom se radu raspravlja o modifikaciji i komplementaciji kao dvama temeljnim sintagmatskim odnosima u kontekstu analize imenskih sintagmi s odglagolnim i relacijskim imenicama. Naime u hrvatskim se gramatikama često govori o dopunama, pa čak i objektima, imenica, što je s teorijskoga aspekta vrlo problematično jer imenice kao nerelacijske nezavisne sastavnice nominala podliježu modifikaciji, a ne komplementaciji. Budući da su odglagolne i relacijske imenice hibridne kategorije, odnosno osim što profiliraju stvar, one u konceptualnoj bazi sadrže i defokusirani proces ili odnos, u raspravu se uvode pojmovi eksplicitne modifikacije i implicitne komplementacije koji pak rezultiraju kategorijom dopunskih modifikatora, za koje smatramo da najpreciznije karakteriziraju narav sintaktičkih jedinica s kojima odglagolne i relacijske imenice tvore imensku sintagmu.

Ključne riječi: odglagolne imenice, modifikacija, komplementacija, dopunski modifikatori

\section{UVOD}

Kada se razmišlja i raspravlja o vrstama riječi, pogotovo o sličnostima i razlikama među njima, jedna je od prvih asocijacija bez ikakve sumnje razlika između glagola i imenica kao najvažnijih i prototipnih vrsta riječi u smislu predikativnosti i argumentne strukture, što pak za posljedicu ima njihovo semantičko i funkcionalno suprotstavljanje. Budući da označavaju radnju (u 
najapstraktnijem smislu), glagoli pripadaju relacijskim vrstama riječi (relacijskim predikacijama) zbog odnosa koji uspostavljaju među aktantima koji na sintaktičkoj razini čine njihovu argumentnu strukturu. Točnije glagoli su vremenske relacijske predikacije zbog čega se u kognitivnoj gramatici njihov semantički pol i definira kao shematičan [PROCES], što znači da svaki glagol, bez obzira o kojem se semantičkom tipu radi, u svojoj semantičkoj strukturi sadrži više ili manje profiliranu domenu vremena te podliježe kognitivnoj operaciji sekvencijskoga promatranja (engl. sequential scanning). Nasuprot procesualnoj naravi glagola koji označavaju vrstu aktivnosti, odnosno ono što se radi, imenice predstavljaju entitete u izvornoj i ciljnoj domeni lanca radnje, pokretače i predmete radnje, te se njihov semantički pol shematično definira kao [STVAR] - omeđeno područje u nekoj domeni - i tumače se kognitivnom operacijom skupnoga promatranja (engl. summary scannin$g)^{1}$ (sl. 1), a navedena razlika posebice dolazi do izražaja kada se u obzir uzmu prototipni ostvaraji tih dviju vrsta riječi - konkretne imenice i glagoli radnje. Drugim riječima, imenice u tom smislu predstavljaju najveći otklon od značenja procesualnosti te su u hijerarhiji opredmećivanja koja prema Langackeru (1991: 423) glasi proces > složena nevremenska relacija > jednostavna nevremenska relacija > stvar ${ }^{2}$ suprotstavljene glagolima.

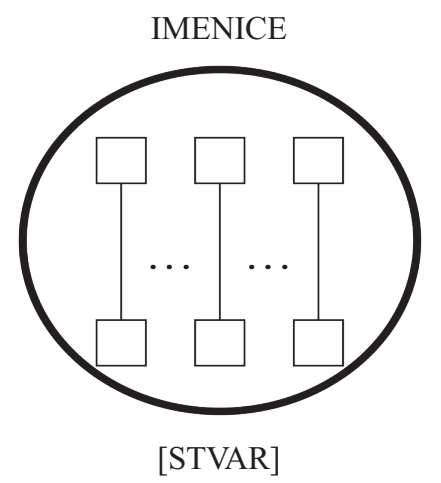

1 Uz imenice skupnom promatranju podliježu i složene i jednostavne nevremenske relacijske predikacije (prilozi, pridjevi i prijedlozi). O skupnom i sekvencijskom promatranju u kontekstu analize imenica i glagola, ali i drugih gramatičkih fenomena vidi više u Langacker (1987a, 1987b, 1991, Taylor 2002 te u Belaj i Tanacković Faletar 2014), a općenito o vrstama riječi u hrvatskom jeziku iz aspekta kognitivne gramatike u Belaj i Tanacković Faletar (2014).

2 Složene nevremenske relacije jesu one koje profiliraju složenije prostorne odnose, npr. prijedlozi kroz, preko ili oko (npr. drveće oko kuće, cesta kroz planinu, most preko rijeke), koji podrazumijevaju prostiranje trajektora duž orijentira, a jednostavne nevremenske relacije profiliraju pojedinačnu konfiguraciju (npr. lopta ispod stola). 


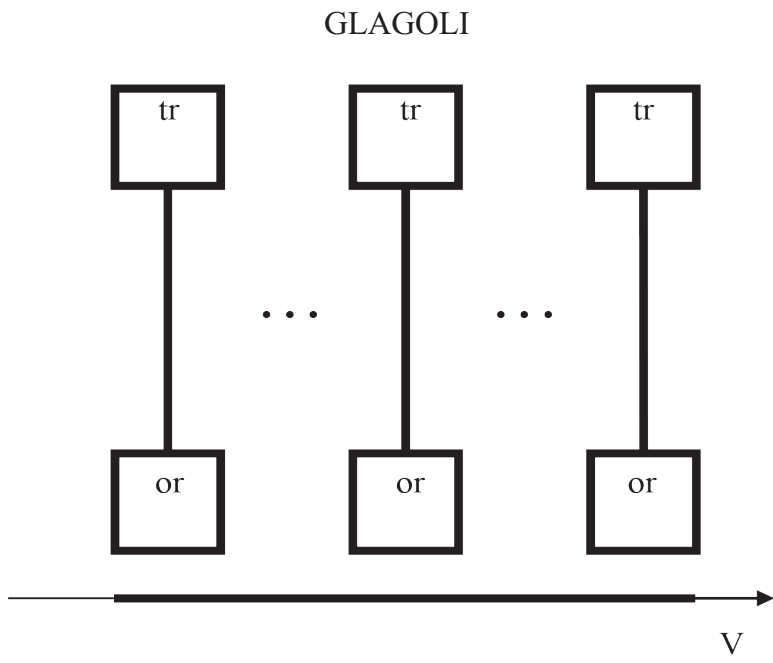

[PROCES]

Slika 1

Također, a s obzirom na definiciju semantičkoga pola imenica i glagola, imenice posljedično predstavljaju konceptualno neovisne entitete, dok konceptualizacija glagola ovisi o prisutnosti aktanata, odnosno sudionika radnje - trajektora i orijentira kao njezinih dviju podstruktura. Relacijska narav glagola koja proizlazi iz odnosa prema aktantima procesa najbolje se vidi na primjeru bezličnih konstrukcija s glagolima koji označavaju vremenske prilike (verba meteorologica), kao što su Kiši, Sniježi, Puše, Sijeva itd., gdje defokusiranje i detopikalizacija vršitelja rezultira težom konceptualnom dostupnošću procesa koje takvi glagoli označavaju. Da budemo slikoviti, takva se sintaktičko-semantička konstelacija može usporediti recimo s pokušajem konceptualizacije žice bez uključivanja stupova koji ju drže ili s pokušajem konceptualizacije prsta bez šake. Drugim riječima, aktanti zapravo funkcioniraju kao neposredna baza ili netemeljna domena (Langacker 1987a, 2008, Taylor 2002), odnosno neposredni konceptualni kontekst nekoga procesa. Slučaj je to u svim bezličnim konstrukcijama, a dobar je primjer sintaktičkih implikacija toga i usporedba tzv. obezličenih i refleksivnopasivnih konstrukcija s konkretiziranim agensom. U našim je normativnim gramatikama dobro poznata činjenica da konkretiziranje agensa nije moguće ni u jednom ni i u drugom slučaju (za razliku od drugih 
semantičkih mikrouloga, npr. ne-voljnoga agensa, sredstva ili efektora), pa se jednako neovjerenima s jedne strane smatraju i konstrukcije tipa *Priča se o tome od njih $i$ *Gradi se novu prugu od strane radnika Hrvatskih željeznica kao i refleksivnopasivna konstrukcija *Gradi se nova pruga od strane radnika Hrvatskih željeznica. No dok za bezlične konstrukcije tvrdnja o apsolutnoj neovjerenosti stoji, kod refleksivnopasivnih konstrukcija to nije tako, a što se povremeno potvrđuje i u korpusu. Refleksivnopasivna konstrukcija s konkretiziranim agensom obilježena je i rijetka, ali nije apsolutno neovjerena, što je s jedne strane rezultat odmaka od značenja bezličnosti, a s druge strane intuitivne veze s pasivnim konstrukcijama koje se tvore trpnim pridjevom i glagolom biti, u kojima je konkretiziranje agensa moguće. ${ }^{3}$ Tako je to u prototipnim slučajevima, no gramatičke se kategorije ne svode samo na njih već čine kontinuum mnogobrojnih prijelaznih i hibridnih slučajeva, gdje stvari nisu toliko jasne. Dobar je primjer toga recimo infinitiv, koji s glagolima povezuju samo tzv. unutarnje kategorije vida i prijelaznosti, čime se smanjuje njegova relacijska narav te se približava imenicama (odglagolnim) i često je njima i zamjenjiv (usp. Planinariti je zdravo/Planinarenje je zdravo). S druge strane, a s obzirom na definiciju semantičkoga pola kao [STVARI], u kategoriji imenica problematičnije su primjerice tvarne (gradivne ili nebrojive) imenice koje se ne mogu smatrati omeđenim područjem u domeni fizičkoga prostora, već se omeđuju u domeni tzv. kvalitativnoga prostora (usp. Langacker 1991: 18; Belaj i Tanacković Faletar 2014: 64). Među imenicama također ima hibridnih kategorija i s obzirom na profiliranje odnosa, tj. približavanje relacijskim vrstama riječi. Takve hibridne kategorije predstavljaju odglagolne imenice, relacijske imenice kojima se označavaju rodbinski odnosi (npr. sestra, brat, ujak) te npr. adverbijalizirane imenice tipa brdo, hrpa, masa i sl. (npr. brdo novaca, hrpa ljudi, masa prosvjednika) (usp. Belaj i Tanacković Faletar 2014: 97, 192). Ovdje ćemo se detaljnije posvetiti odglagolnim i relacijskim imenicama, točnije pitanju mogućnosti njihove komplementacije, odnosno pitanju treba li sastavnice s kojima se one sintagmatski kombiniraju tumačiti kao modifikatore ili kao dopune. ${ }^{4}$

3 O značenju i sintaksi bezličnih konstrukcija vidi više u Belaj (2007) i u Belaj i Tanacković Faletar (2017: 129-144), a o odnosu refleksivnopasivnih i bezličnih konstrukcija u Kučanda (1992) i Belaj (2004).

4 Postoje još i dvostrukorelacijske imenice tipa oproštaj ili sjećanje (usp. Belaj i Tanacković Faletar 2014: 105) koje su zapravo kombinacija odglagolnih i relacijskih imenica jer osim što u bazi sadrže referenciju na proces, uključuju također i referenciju na neku drugu imenicu (npr. 


\section{RASPRAVA}

Kada su u pitanju sintagmatski odnosi, kognitivna gramatika, kao uostalom i mnoge druge gramatičke teorije, ističe modifikaciju i komplementaciju kao dva temeljna aspekta ustroja gramatičkih struktura ne samo na razini sintagme ili skupine već na svim razinama - od razine riječi pa do složene rečenice. No za razliku od ostalih teorija kognitivna gramatika uvodi termin konceptualne zavisnosti (engl. A/D alignment) na temelju kojega se određuje status odrednika profila (glave) u odnosu na modifikator ili dopunu s kojima tvori neku sintaktičku skupinu (sl. 2, prema Belaj i Tanacković Faletar 2014: 181).

a) komplementacija

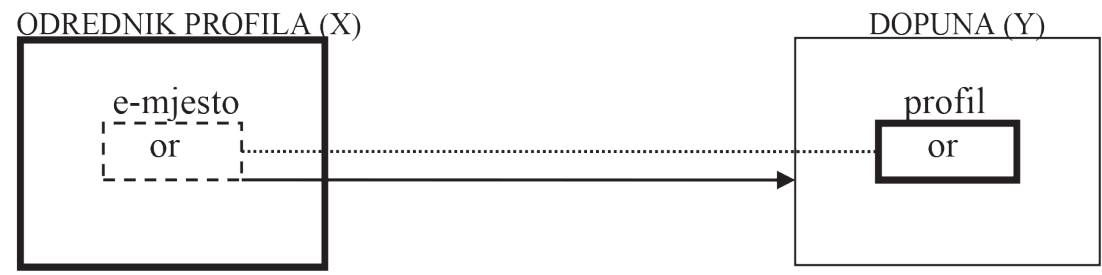

ZAVISNA

NEZAVISNA

b) modifikacija

ODREDNIK PROFILA(X)

MODIFIKATOR (Y)

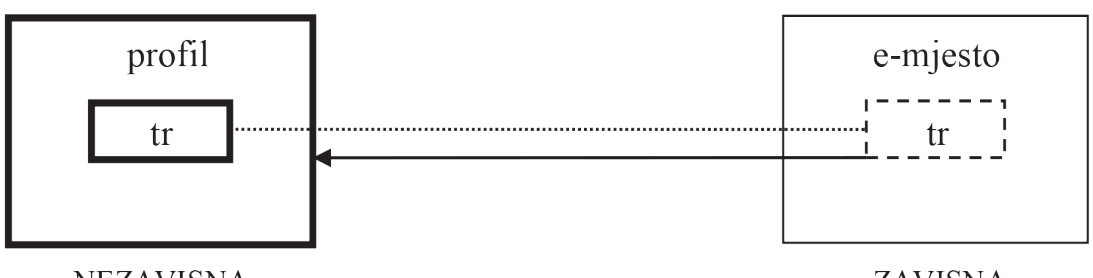

Slika 2

oproštaj ratnika, sjećanje prijatelja itd.). Njima se ovdje nećemo baviti jer za njih vrijedi sve što je rečeno o ovim dvama temeljnim tipovima hibridnih imenica. 
U slučaju je komplementacije odrednik profila zavisna sastavnica $\mathrm{u}$ smislu da je konceptualno ovisan o dopuni kao nezavisnoj sastavnici koja elaborira neko prazno shematično mjesto (e-mjesto, engl. elaboration site, e-site) u njegovoj semantičkoj strukturi, odnosno dopuna funkcionira kao elaboracija neke potencijalne i nužne podstrukture kojoj mjesto otvara odrednik profila. Ta je podstruktura kod komplementacije u pravilu orijentir. ${ }^{5}$ Kod modifikacije je pak situacija obrnuta jer kao zavisna sastavnica funkcionira modifikator koji u svojoj semantičkoj strukturi sadrži prazno mjesto elaboracije u vidu shematičnoga trajektora konstrukcije, a koje popunjava odrednik profila kao nezavisna sastavnica. Prototipove tih dvaju odnosa predstavljaju glagoli i imenice kao odrednici profila. ${ }^{6} \mathrm{U}$ tom smislu posebno su zanimljive odglagolne imenice kao kombinacija imenica i glagola, pa se postavlja pitanje kako tumačiti imenske sintagme u kojima odglagolne imenice funkcioniraju kao odrednik profila - kao modifikacijske ili komplementacijske?

Odglagolne imenice kao hibridna kategorija specifične su po tome što svojom pripadnošću imenicama kao prototipnoj nerelacijskoj kategoriji profiliraju [STVAR] te posljedično podliježu modifikaciji, kao nezavisne sastavnice nominala (NP-a ili imenske sintagme), ali njihova je konceptualizacija istovremeno nemoguća bez aktivacije značenja glagola od kojega se tvore. One dakle imaju [PROCES] u bazi, odnosno proces im služi kao neposredan konceptualni kontekst, što pak znači da konceptualizacija odglagolne imenice nije moguća bez svijesti o procesu s kojim su povezane, ali je taj proces defokusiran, odnosno nije profiliran. Ono što je profilirano skupnim promatranjem pozadinske vremenske relacije jest stvar, pa se za odglagolne imenice s pravom kaže da predstavljaju opredmećeni proces (sl. 3) jer značenjska interpretacija jezičnih jedinica ne ovisi samo o profilu, već i o konceptualnoj bazi, odnosno o njihovoj paralelnoj aktivaciji:

Semantička vrijednost nekoga izraza nije sadržana ni samo u bazi ni samo u profilu, već u njihovu prožimanju; drugim riječima značenjska se

5 Kaže se u pravilu jer ne mora uvijek biti tako. Primjerice kod obveznih adverbijalnih dopuna (npr. On stanuje u Osijeku, Držao se hrabro, Agresija proizlazi iz straha) nije riječ o orijentiru kao e-mjestu, već o shematičnom odnosu sadržanom u semantičkoj strukturi glagola, a elaboriranim nekim svojstvom ili okolnošću kao obveznom adverbijalnom dopunom (usp. Langacker 2008: 360 i Belaj i Tanacković Faletar 2017: 239).

6 Osim glagola komplementaciji podliježu, odnosno imaju dopune kao odrednici profila, i prijedlozi (npr. na stolu), prilozi u vezanim spojevima riječi (npr. mnogo ljudi) i neki pridjevi (npr. željan pažnje), dok modifikaciji uz imenice kao odrednici profila imenskih sintagmi podliježu i neke zamjenice, u prvom redu lične (npr. mi stariji). 
vrijednost izraza izvodi iz prepoznavanja nekog specifičnog entiteta koji se identificira i karakterizira u odnosu na svoj položaj u okviru neke šire konceptualne konfiguracije (Langacker 1987a: 183). ${ }^{7}$

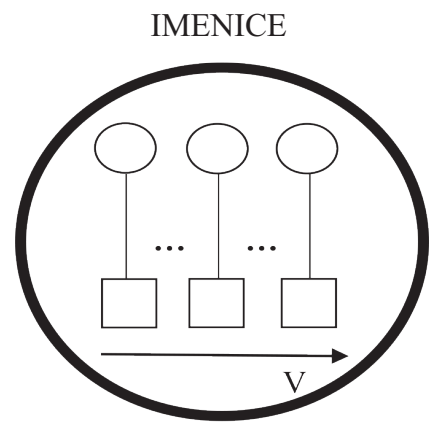

[STVAR]

Slika 3

Iako procesualnost već po samoj naravi stvari nije profilirana ni kod jedne odglagolne imenice, ona ipak u konceptualnoj bazi može biti manje ili više istaknuta, a ovisno o kojoj je vrsti odglagolne imenice riječ. S obzirom na značenje glagola s kojim su povezane odglagolne imenice mogu se podijeliti u četiri skupine prema tome označavaju li s jedne strane događaj ili stanje te s druge strane jesu li oni epizodične ili trajne naravi. Kombinacijom tih dvaju kriterija dobivaju se (i) trajna stanja (npr. znanje), (ii) epizodična stanja (npr. sumnja), (iii) trajni događaji (npr. popravljanje) i (iv) epizodični događaji (npr. popravak). ${ }^{8}$ Tako će kod odglagolnih imenica događajne semantike procesualnost biti izraženija, a kod onih koje označavaju stanja manje izražena, pa se s obzirom na kriterij relativne istaknutosti procesualnosti u bazi može napraviti sljedeća hijerarhija odglagolnih imenica, od onih s manje istaknutom procesualnošću prema istaknutijoj: trajna stanja > epizodična stanja > epizodični događaji > trajni događaji (sl. 4).

\footnotetext{
"The semantic value of an expression resides in neither the base nor the profile alone, but only in their combination; it derives from the designation of a specific entity identified and characterized by its position within a larger configuration."

$8 \mathrm{O}$ toj podjeli u kontekstu rasprave o vezi odglagolnih imenica s konceptima omeđenosti i neomeđenosti, odnosno s brojivim i nebrojivim imenicama, vidi više u Radden i Dirven (2007: 78-86) te u Belaj i Tanacković Faletar (2014: 98-105).
} 
a) TRAJNA STANJA

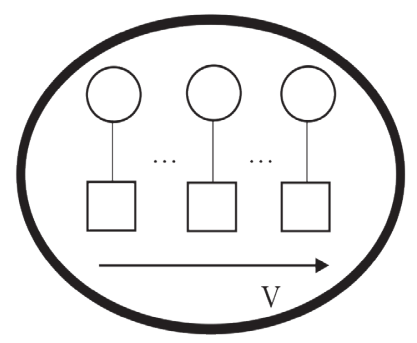

c) EPIZODIČNI DOGAĐAJI

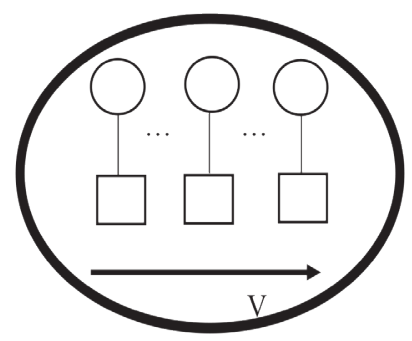

b) EPIZODIČNA STANJA

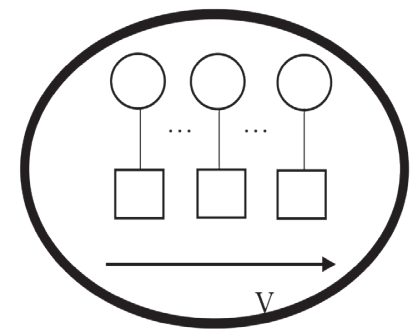

d) TRAJNI DOGAĐAJI

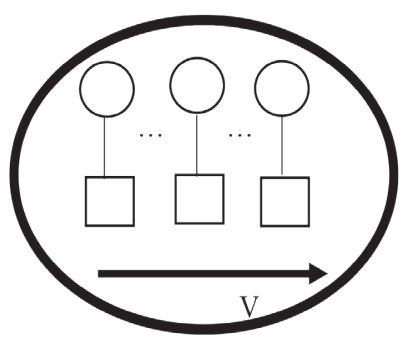

Slika 4

Tu su još i agentivne i trpne odglagolne imenice (npr. prodavač, zaposle$n i k)$, kod kojih će istaknutost pozadinske procesualnosti također ovisti o tipu glagola od kojega se tvore. Međutim manja ili veća istaknutost procesualnosti u bazi ne govori puno o tome treba li imenice ili imenske sintagme koje stoje uz odglagolne imenice tumačiti kao modifikatore ili kao dopune u primjerima tipa znanje matematike, sumnja ljudi, popravak odjeće, pjevanje opere, prodavač voća, zaposlenik tvornice i sl. Neke hrvatske gramatike pojam dopune preširoko shvaćaju, pa dopunom smatraju svaku sastavnicu kojoj mjesto otvara neka druga riječ, pa tako i imenica, smatrajući pri tome svaki rezultat upravljačkih svojstava riječi dopunom. ${ }^{9}$ Takav stav eksplicitno iznose npr. Katičić (1991) i Barić i dr. (1995), koji čak govore i o objektima kao užem pojmu od dopune, odnosno vrsti dopune, što je potpuno neprihvatljivo već

9 Kudikamo je prihvatljivije rješenje koje iznose Silić i Pranjković (2005: 262-266) jasno razgraničavajući gramatičke veze među sastavnicama riječi (sročnost, upravljanje i pridruživanje) od funkcionalnih svojstava spojeva riječi (odredbenih, dopunskih i okolnosnih). 
zbog same definicije objekta kao predmeta radnje ${ }^{10}$ : "Takve imenice koje se dodaju pojedinim rečeničnim dijelovima jer oni bez njih nisu potpuni zovu se njihove dopune [...] Dopune se prema svojim imenicama i pridjevima odnose kao objekti prema svojem glagolu. Neke se imenice dopunjuju instrumentalom koje sklonjive riječi. Takve su bogataš, siromah" (Katičić 1991: 125, 126). "Osim glagola neizravnom objektu u instrumentalu otvaraju mjesto i neke druge predikatne riječi. Takve su: 1. imenice: trgovac, velikan, siromah, bogataš [...]" (Barić i dr. 1995: 442). Osim toga što se govori o objektima imenica, metodološki je također pogrešno u istu kategoriju svrstavati odglagolne imenice kao što je trgovac (trgovac žitom) i one koje to nisu jer uz imenice tipa siromah (siromah stokom) i bogataš (bogataš stokom) ne samo da nije riječ o objektima nego nije riječ ni o dopunama, već klasičnim primjerima postmodifikatora. Međutim kada su u pitanju odglagolne imenice, takve tvrdnje ne mogu se u potpunosti odbaciti jer one kao hibridna kategorija uz semantička i tvorbena obilježja glagola, a u skladu s jednom od temeljnih teza kognitivne gramatike prema kojoj gramatika simbolizira značenje, nužno nasljeđuju i neka njihova sintaktička obilježja. Stoga se kao logično i razumno rješenje i u analizi sintagmatskih odnosa u kojima se one pojavljuju također nameće svojevrsno hibridno, tj. interkategorijalno rješenje. Budući da odglagolne imenice kao i sve druge imenice profiliraju stvar kognitivnom operacijom skupnoga promatranja, posljedično će kao i kod ostalih imenica biti profiliran i odnos modifikacije. No kako one istovremeno od glagola nasljeđuju i procesualnost koja u bazi funkcionira kao neizostavan konceptualni kontekst, naslijedit će u bazi i komplementaciju kao sintaktičko obilježje glagola. Drugim riječima, kod odglagolnih imenica može se govoriti o eksplicitnoj modifikaciji i implicitnoj komplementaciji, što pak onda, slično kao i u nekim pridjevskim skupinama (usp. Belaj i Tanacković Faletar 2017: 244-253), i kod odglagolnih imenica rezultira mogućnošću uvođenja sintaktičke kategorije dopunskih modifikatora kao posljedice suodnosa eksplicitne modifikacije i implicitne komplementacije. Kako odglagolne imenice, a što dobro primjećuje i Fillmore (1994: 106), ${ }^{11}$ uključuju (ali ne profiliraju) istu argumentnu strukturu kao i glagol s kojim su u tvorbenoj vezi, sintaktičke sastavnice s kojima odglagolne imenice stupaju

10 Iako se i domaćoj i u stranoj literaturi objekt počesto vrlo široko shvaća i upotrebljava praktički sinonimno nazivu dopuna (govori se tako primjerice i o objektima prijedloga), smatram da o objektu treba govoriti isključivo u kontekstu glagolskih dopuna.

11 " $[\ldots]$ and there are nouns derived from verbs which incorporate (istaknuo B.B.) the same argument structures as their source verb." 
u sintagmatske odnose mogu se s jedne strane analizirati kao defokusirane implicitne dopune (defokusirani implicitni subjekti ili objekti), a s druge strane kao profilirani eksplicitni modifikatori. Štoviše, u tom se smislu može govoriti o implicitnoj vanjskoj komplementaciji u slučaju subjektnoga genitiva (npr. sjećanja junaka) te o implicitnoj unutarnjoj komplementaciji kod objektnoga genitiva (npr. operacija ranjenika). ${ }^{12}$ Nasljeđivanje argumentne strukture glagola u nekim konstrukcijama kao posljedicu ima sintaktičko-semantički paralelizam između odglagolne imenice i glagola. Može se o tome primjerice govoriti u konstrukcijama s glagolima široka značenja ${ }^{13}$ koji zahtijevaju obveznu objektnu dopunu i paralelnim perifraznim konstrukcijama s odglagolnim imenicama koje će tada zahtijevati obvezni dopunski modifikator, pa će i komplementacijska svojstva biti nešto izraženija nego tamo gdje nije riječ o obveznim dopunama, usp.:

(1) Dok je prodavao rabljene automobile, dobro je zarađivao. / *Dok je prodavao, dobro je zarađivao.

(1a) Dok se bavio prodajom rabljenih automobila, dobro je zarađivao. / *Dok se bavio prodajom, dobro je zarađivao.

(2) Dok je popravljao rabljene automobile, dobro je zarađivao. / *Dok je popravljao, dobro je zarađivao.

(2a) Dok se bavio popravljanjem rabljenih automobila, dobro je zarađivao. / *Dok se bavio popravljanjem, dobro je zarađivao.

Nadalje isto kao što su konstrukcije s takvim glagolima ovjerene kada se oni upotrebljavaju u generičkom značenju označavajući tip aktivnosti, takva je upotreba svojstvena i konstrukcijama s odglagolnim imenicama, usp.:

(3) On pjeva.

(3a) On se bavi pjevanjem.

(4) Ivana piše.

(4a) Ivana se bavi pisanjem.

Isto je i u slučajevima s neleksikaliziranim objektima u kojima je riječ o glagolima koji formalno otvaraju mjesto različitim objektnim dopunama,

12 Iako termini vanjska i unutarnja implicitna komplementacija podrazumijevaju termine vanjski i unutarnji argument koji svakako ne pripadaju teorijsko-metodološkom okviru kognitivne gramatike, ovdje se ipak upotrebljavaju jer dobro pokrivaju problematiku, a i metodološki eklekticizam u određenoj mjeri nikada nije naodmet.

13 O tim i ostalim konstrukcijama s različitim semantičkim tipovima direktnoga objekta u akuzativu te o kognitivnogramatičkom pristupu kategoriji prijelaznosti općenito vidi više u Rice (1987), a u kontekstu hrvatskoga jezika u Belaj i Tanacković Faletar (2017: 153-183). 
no metonimijski se (CJELINA ZA DIO > TIP AKTIVNOSTI ZA VRSTU AKTIVNOSTI) izbor sužava na jednu prototipnu (5-5a) ili u slučajevima gdje je objekt značenjem glagola sužen na jedan tip (6-6a), usp.:

(5) Marko je nedavno prestao pušiti (cigarete / *cigare / *lulu / *travu).

(5a) Marko je nedavno prestao s pušenjem (cigareta / *cigara / *lule / *trave).

(6) Od svih fizičkih poslova najviše voli kopati (zemlju).

(6a) Od svih fizičkih poslova najviše voli kopanje (zemlje).

Odnosi eksplicitne modifikacije i implicitne komplementacije (unutarnje) prikazani su na sl. 5 integracijom imenica pjevanje i opera u kompozitnu konstrukciju pjevanje opere u kojoj se opere tumači kao dopunski modifikator odglagolne imenice pjevanje kao odrednika profila. ${ }^{14}$ Odglagolna imenica i pri jednoj i pri drugoj interpretaciji funkcionira kao odrednik profila te je naznačena debljim pravokutnikom. Eksplicitna modifikacija prikazana je u desnom pravokutniku gore, pri čemu postmodifikator opere kao orijentir u svojoj semantičkoj strukturi sadrži prazno e-mjesto trajektora koje elaborira (označeno strelicom) odglagolna imenica pjevanje kao odrednik profila i nezavisna sastavnica. S druge strane implicitna komplementacija kao posljedica prisutnosti defokusiranoga procesa u semantičkoj bazi odglagolne imenice prikazana je unutar isprekidanoga ovala. U tom slučaju odglagolna je imenica kao odrednik profila zavisna sastavnica koja isto kao i glagol u svojoj semantičkoj strukturi sadrži prazno e-mjesto orijentira elaborirano dopunom opere.

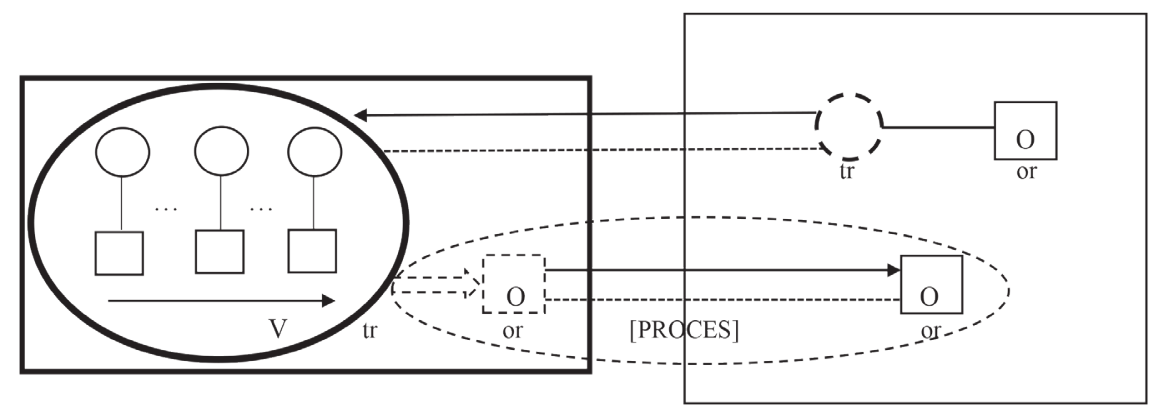

Slika 5

14 Niže i viša integracijska razina izostavljene su iz prikaza jer za ovu raspravu nisu relevantne. Niže se integracijske razine odnose na integraciju sufiksa -nj(e) kao odrednika profila i tvorbene osnove kao dopune, čime se dobiva odglagolna imenica pjevanje te gramatičkoga morfema - $e$ kao modifikatora i morfološke osnove kao odrednika profila, čime se dobiva opere. 
Važno je također istaknuti da se o implicitnoj komplementaciji kod odglagolnih imenica može govoriti samo onda kada eksplicitni modifikator korelira s direktnim ili indirektnim objektom kao dopunom imenici paralelnoga glagola, usp. prijedlog opomene > predložiti opomenu, strah od letenja > strašiti se letenja, zahvala kolegi > zahvaliti kolegi, razgovor o temi $>$ razgovarati o temi, trgovanje žitom $>$ trgovati žitom. U slučajevima u kojima postmodifikator ne korelira s objektom glagola, nego s adverbijalnim modifikatorom (adjunktom) u glagolskoj konstrukciji, implicitna je komplementacija isključena i riječ je o čistoj postmodifikaciji, usp. prijedlog iz očaja > predložiti iz očaja, strah bez osnove > strašiti se bez osnove, zahvala od srca > zahvaliti od srca, razgovor bez smisla > razgovarati bez smisla, trgovanje (trgovina) na malo > trgovati na malo. Također, o implicitnoj se komplementaciji, odnosno dopunskim modifikatorima, može govoriti i onda kada je riječ o složenim modifikacijskim izrazima, prijedložnim padežnim izrazima ili zavisnim klauzama, kao pandanima jednočlanih imeničkih dopunskih modifikatora, usp. prijedlog opomene / prijedlog zа оротепи / prijedlog da se izrekne opomena.

Preostaje nam još nešto reći o odnosima modifikacije i komplementacije kod relacijskih imenica čija konceptualizacija ovisi o referenciji na neki drugi entitet s kojim su one povezane odnosom porijekla. Takve su imenice u prvom redu one koje označavaju različite rodbinske odnose (npr. brat, sestra, majka, otac, ujak itd.), ali i one koje ovise o konceptualnoj aktivaciji međuljudskih ili poslovnih odnosa (npr. prijatelj ili suradnik). Dakle isto kao što odglagolne imenice u bazi sadrže referenciju na glagol, odnosno na vremensku relacijsku predikaciju sa semantičkim polom [PROCESA], tako i relacijske imenice u svojoj bazi sadrže semantički pol [ODNOSA] koji uspostavljaju s nekim entitetom kao orijentirom i koji je svojstven nevremenskim relacijskim predikacijama (sl. 6).

Sintaktička posljedica takve konceptualne konstelacije jest obvezna prisutnost modifikatora (bilo leksikaliziranog bilo kontekstualno uključenog), odnosno determinatora s aspekta semantičkoga ustroja takvih imenskih sintagmi, ${ }^{15}$ pa za razliku od drugih imenica relacijske imenice ne mogu biti

15 Iznimno je važno razlučiti modifikaciju u kontekstu sintagmatskih aspekata ustroja imenske sintagme i modifikaciju kao semantičku kategoriju. U prvom se slučaju modifikator upotrebljava u značenju tradicijskoga naziva atribut i tada se suprotstavlja dopuni, a sa semantičkoga su aspekta modifikatori suprotstavljeni determinatorima i kvantifikatorima kao sredstvima usidrenja (referencije) imenske sintagme. U semantičkom dakle smislu modifikacija se vezuje 


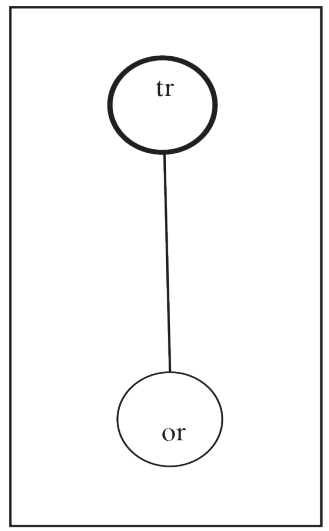

Slika 6

upotrijebljene na razini tipa ${ }^{16}$ već isključivo kao determinirane usidrene varijante, najčešće posvojnim pridjevom, posvojnom zamjenicom ili posvojnim dativom, usp.:

(7) Jučer sam u šetnji sreo malog kuštravog psa.

(7a) Jučer sam u šetnji sreo tvog malog kuštravog psa.

(8) *Jučer sam u šetnji sreo malu kuštravu sestru.

(8a) Jučer sam u šetnji sreo Ivanovu malu kuštravu sestru.

(8b) Jučer sam u šetnji sreo tvoju malu kuštravu sestru.

(8c) Jučer sam ti u šetnji sreo malu kuštravu sestru.

Dakle kada je u pitanju prisutnost komplementacijskih obilježja relacijskih imenica, one su vrlo slične odglagolnim imenicama jer osim što je i kod njih profiliran odnos modifikacije, opisani odnos koji uspostavljaju u konceptualnoj bazi kao neizostavnom aspektu značenja čini ih i zavisnim sastavnicama sintagme, što pak uvjetuje njihov opis i u okvirima komplementacije. Štoviše, kod relacijskih je imenica riječ o obveznim dopunama, dok kod odglagolnih imenica to ne mora biti slučaj te je zbog toga kod relacijskih imenica možda još i opravdanije govoriti o dopunskim modifikatorima kao posljedici eksplicitne modifikacije i implicitne komplementacije.

uz razinu tipa i uključuje opisne, odnosne i gradivne pridjeve, dok se determinatori (posvojni pridjevi, posvojne zamjenice, demonstrativi i članovi) i djelomično kvantifikatori (relativni) kao sredstva usidrenja odnose na razinu varijantnosti. O tim pitanjima vidi detaljno u Belaj i Kuna (2013) i Belaj i Tanacković Faletar (2014:117-175).

16 Osim u generičkim kontekstima tipa Majke se u pravilu vole više od očeva. 
Sl. 7 prikazuje eksplicitnu modifikaciju (odnos izvan ovala) i implicitnu vanjsku ${ }^{17}$ komplementaciju, odnosno dopunsku modifikaciju, relacijskih imenica na primjeru konstrukcije njegov brat, a koja se od dopunske modifikacije odglagolnih imenica (sl. 5) razlikuje i po semantičkoj naravi relacije sadržane u konceptualnoj bazi - ovremenjenom ili procesualnom odnosu imanentnom glagolima kao vremenskim relacijskim predikacijama kod odglagolnih imenica te atemporalnom odnosu svojstvenom nevremenskim relacijskim predikacijama kod relacijskih imenica.

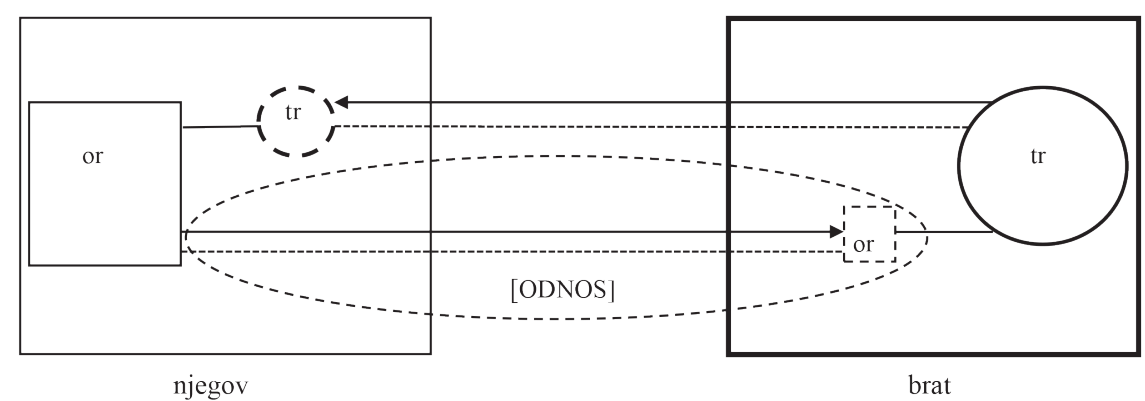

Slika 7

Također vrlo je važno obvezne dopunske modifikatore relacijskih imenica razgraničiti od obveznih kompozitnokonstrukcijskih modifikatora (obveznih atributa), čija obvezatnost nije inherentna njima samima, a ni značenju imenice koju modificiraju, već proizlazi iz odnosa cijele sintagme koju tvore zajedno s imenicom prema imenici koju modificiraju ili rečenici ako je riječ o adverbijalnim modifikatorima. Drugim riječima, njihova obvezatnost proizlazi iz značenjskih odnosa u kompozitnim konstrukcijama, odnosno u konstrukcijama višega reda, pa stoga i ne funkcioniraju kao obvezne dopune koje bi osiguravale gramatičnost i izvan takvih složenijih konstrukcija, a što je slučaj s relacijskim imenicama (usp. Ošišala je kosu / Ošišala je crnu kosu, ali *Voli žene kose / Voli žene crne kose). Takvi su kompozitnokonstrukcijski obvezni modifikatori primjerice kvalitativni genitiv (npr. žena crne kose /*žena kose), kvalitativni instrumental ili instrumental karakteristične pojedinosti (npr. žena s crnom kosom / *žena s kosom), vremenski genitiv

Riječ je o vanjskoj komplementaciji jer konstrukcija njegov brat pretpostavlja konstrukciju On ima brata, odnosno posvojna zamjenica semantički korelira sa subjektom koji bi u tom slučaju imao funkciju trajektora, a objekt orijentira, no zbog jednostavnosti prikaza taj je odnos izostavljen na sl. 7. 
(npr. Stižemo sljedećeg tjedna /*Stižemo tjedna), vremenski akuzativ (npr. Stižemo sljedeći tjedan /*Stižemo tjedan) te genitiv vremenske mjere (npr. Čekali smo ih cijele godine / ${ }^{*}$ Čekali smo ih godine).${ }^{18}$

\section{ZAKLJUČAK}

Zaključno se može reći da iako sintaktički odnosi modifikacije i komplementacije načelno predstavljaju dva oprečna odnosa, oni se, kao uostalom i sve druge kategorije, kako leksičke tako i gramatičke, u nekim slučajevima i preklapaju. Kao što se i vidjelo, dvije su kategorije imenica - odglagolne i relacijske - dobar primjer takva njihova preklapanja jer je sintaktička narav tih imenica kao hibridnih i rubnih imeničkih kategorija posljedica njihove semantičke naravi koja uključuje i značenjski profil i značenjsku bazu kao neizostavni konceptualni kontekst, točnije obvezni preduvjet interpretacije njihova značenja.

\section{LITERATURA}

Barić, Eugenija, Mijo Lončarić, Dragica Malić, Slavko Pavešić, Mirko Peti, Vesna Zečević, Marija Znika. 1995. Hrvatska gramatika. Zagreb: Školska knjiga.

Belaj, Branimir. 2004. Pasivna rečenica. Filozofski fakultet: Osijek.

Belaj, Branimir. 2007. Konceptualnosemantički aspekti prototipnih struktura s bezličnim i obezličenim glagolima i njihove sintaktičke implikacije. Branko Kuna (ur.) "Sintaktičke kategorije", Osijek: Filozofski fakultet, 21-50.

Belaj, Branimir i Branko Kuna. 2013. O kognitivnim temeljima položaja modifikatora, determinatora i kvantifikatora u imenskoj sintagmi. "Rasprave: Časopis Instituta za hrvatski jezik i jezikoslovlje", 39/2, 311-344.

Belaj, Branimir i Goran Tanacković Faletar. 2014. Kognitivna gramatika hrvatskoga jezika, Knjiga prva, Imenska sintagma i sintaksa padeža. Zagreb: Disput.

Belaj, Branimir i Goran Tanacković Faletar. 2017. Kognitivna gramatika hrvatskoga jezika, Knjiga druga, Sintaksa jednostavne rečenice. Zagreb: Disput.

Fillmore, Charles, J. 1994. The Hard Road from Verbs to Nouns. "In honor of William S-Y. Wang: Interdisciplinary Studies on Language and Language Change”. Taipei, Taiwan, ROC: Pyramid Press, 105-129.

18 O tim pitanjima pod nazivom obvezna determinacija vidi više u Ivić $(1962,1964,1983)$ i Radovanović (1990), pod nazivom obvezna atribucija u Znika (1988), a pod nazivom obvezni kompozitnokonstrukcijski modifikatori u Belaj i Tanacković Faletar (2017). 
Ivić, Milka. 1962. The grammatical category of non-omissible determiners. "Lingua" 11: 199-204.

Ivić, Milka. 1964. Non-omissible determiners in Slavic Languages. "Proceedings of the Ninth International Congress of Linguists", The Hague, 476-479.

Ivić, Milka. 1983. Lingvistički ogledi. Beograd: Prosveta.

Katičić, Radoslav. 1991. Sintaksa hrvatskoga književnog jezika, drugo, ponovljeno izdanje, Zagreb: Globus.

Kučanda, Dubravko. 1992. Funkcionalni pristup analizi pasiva u hrvatskom. "Suvremena lingvistika", 18, 175-184.

Langacker, Ronald, W. 1987a. Foundations of Cognitive Grammar, Vol. 1. Stanford, California: Stanford University Press.

Langacker, Ronald, W. 1987b. Nouns and Verbs. "Language”, 63, 53-94.

Langacker, Ronald, W. 1991. Foundations of Cognitive Grammar. Vol. 2: Descriptive Application. Stanford, California: Stanford University Press.

Langacker, Ronald, W. 2008. Cognitive Grammar. A Basic Introduction. Oxford: Oxford University Press.

Radden, Günter i René Dirven. 2007. Cognitive English Grammar. Amsterdam/Philadelphia: John Benjamins.

Radovanović, Milorad. 1990. Spisi iz sintakse i semantike. Novi Sad: Dobra vest.

Rice, Sally A. 1987. Towards a cognitive model of transitivity. PH.D. dissertation, San Diego: University of California.

Silić, Josip i Ivo Pranjković. 2005. Gramatika hrvatskoga jezika za gimnazije $i$ visoka učilišta. Zagreb: Školska knjiga.

Taylor, John, R. 2002. Cognitive Grammar. New York: Oxford University Press.

Znika, Marija. 1988. Odnos atribucije i predikacije. Zagreb: HFD.

\section{SUMMARY \\ CAN NOUNS HAVE COMPLEMENTS?}

Using the theoretical framework of Cognitive Grammar, this study addresses modification and complementation as two basic types of syntagmatic relations as manifested in nominals featuring deverbal and relational nouns. Croatian grammars often discuss nouns using the concept complement, even object, however, this is theoretically suspect. Nouns are nonrelational, autonomous components of nominal structures and as such lend themselves to modification, not complementation. Since deverbal and relational nouns are hybrid categories, i.e since they profile things but have a defocused process and relation in their conceptual base, we introduce the terms explicit modification and implicit complementation, and the resulting category of complementational modifiers, which, in our view, best characterize the behavior of syntactic units headed by deverbal and relational nouns.

Key words: deverbal nouns, modification, complementation, complementational modifiers 